INTERNATIONAL HIGHER EDUCATION, NO. 67, Spring, 2012

Pages $19-21$

\title{
Partnerships in Africa in the New Era of Internationalization DAMTEW TEFERRA
}

Damtew Teferra is the founding director of the International Network on Higher Education in Africa at the CIHE. E-mail: teferra@bc.edu.

One of the popular approaches to revitalize higher education in Africa and the buzzword of the sector is currently partnerships. To be sure, higher education in Africa has always been an international affair, owing to its history and trajectory; and, thus, this development may not appear surprising. This article analyzes emerging trends in higher education partnerships in Africa and explores opportunities and challenges, based on recent developments and past experience.

\section{MarketPlace Of Higher Education Partnerships}

It was once thought that Africa would become less attractive to the rest of the world with the cessation of hostilities between the Cold War-era rivals. In 20 years, that prediction proved to be wrong as the contemporary economic and (geo)political realities have prompted the re-engagement of both "historical" and emerging powers regarding Africa.

As part of that larger global reality, higher education in the region has also reignited interest globally-including the European Union, the United States, Canada, China, India, and Brazil. The snapshot of some of these partnerships 
follows.

Africa-US higher education initiative. In July 2007, a group of universities, based in the United States and Africa, came together to launch a partnership initiative to strengthen African higher education's capacity to contribute in priority-development areas. The 2010 US Omnibus Appropriations bill commits US\$15 million for the partnership (http:/ / www.aplu.org).

Canada-Africa higher education partnership. The Association of African Universities (AAU), in partnership with the Association of Universities and Colleges of Canada (AUCC), has launched "Strengthening Higher Education Stakeholder Relations in Africa." This plan's three components include: Strengthening African University Outreach, University-Industry Linkages, and Strengthening AAU Stakeholder Relations working in partnership with AUCC (http://www.aau.org).

Southern Africa-Nordic partnerships. University cooperation between Southern African countries and Nordic university cooperation (SANORD) is a partnership of 25 research-led higher education institutions from Denmark, Finland, Iceland, Norway, and Sweden; and institutions in Malawi, South Africa, and Zambia. SANORD aims to advance multilateral academic collaboration between institutions in the Nordic countries and the Southern African regions, addressing challenges of innovation and development (http:/ / sanord.uwc.ac.za).

European Union-African Union partnership in higher education. The European Union Commission and African Union Commission are partnering, in different schemes, to vitalize the higher education sector in Africa. These include the launching of the Intra-ACP Mobility Scheme, what is now called the Nyrere 
Consolidated Scholarship Program, Harmonization and Tuning Project, and the PanAfrican University Initiative.

Scandinavian partnerships. Partnerships between Scandinavian and African universities is probably a most sustained and impressive cooperation. Norway and Sweden in particular have committed a large sum of funds for several decades, even when support for higher education in Africa was out of favor. At a National Seminar on Norwegian Support to Higher Education in Tanzania in Dar es Salaam, in November 2010, it was reported that NORAD granted in excess of 750 million NOK.

The German Academic Exchange Service (DAAD). For more than two decades, DAAD has also been a significant player of university partnerships in Africa. Currently, there are more than 35 partnerships with one or more African partners. Additionally, five new African centers of excellence and five new international centers of excellence with participation from African universities are supported. A new partnership approach enables the collaboration of DAAD and the German University Association with university associations and higher education regulators on the development of quality-assurance systems (http:/ / www.daad.de).

\section{The “Historical" Partners}

Guided by a variety of objectives and interest, numerous university cooperations between Africa and its other "historical" partners now exist. These include the Austrian Partnership Program in Higher Education and Research for Development (APPEAR), the University Commission for Cooperation with 
Developing countries (CUD, Belgium), the Irish African Partnership for Research Capacity Building (IAP), the Netherlands Organization for International Cooperation in Higher Education (NUFFIC), and the United Kingdom's Education Partnerships for Africa (EPA).

\section{THE EMERging PARTNERS}

Emerging economic and political powers—such as, Brazil, China, and India-are also engaged in a host of university-development support, as well as the capacity-building effort in Africa. Russia and other former eastern bloc countries are also throwing themselves into the act, after two decades of absence from educational engagement in the region. South Africa, the regional powerhouse, is also striving to establish university partnerships with other African countries.

\section{INTERNATIONALIZATION AS INSTRUMENT OF CAPACITY BUILDING}

Needless to say, partnerships are vital for capacity building in teaching, learning, and research. Joint-research activities play an important role in fostering research capacity, nurturing research culture, pushing the frontiers of knowledge, as well

as benchmarking quality. Meticulously developed long-term, joint-research partnerships have shown successful results.

In Ethiopia, for instance, interuniversity cooperations sustained through the support of the Swedish International Development Agency (SIDA) and the Flemish Interuniversity Council-University Development Cooperation (VLIRUOS), in Belgium, have had impressive results. A large pool of PhDs were produced; numerous programs have been developed; and sustainable capacities have been put in place. The same is true for Tanzania through NORAD support. 
Many agree that such results would have simply been impossible without the financial, logistical, and human resources made possible through long-term joint commitment.

\section{NURTURING THE GOOD AND UPROOTING THE BAD}

When capacity building in the context of university cooperation is often invoked, the perceptions are that the southern partners are the predominant, if not the sole, beneficiaries of cooperation. Even more disenchanting is that this perception is often internalized by the southern partners. Yet, while their benefits have not been clearly, and explicitly, documented, the northern partners also gain from the partnerships in many ways.

Even without regard to the immediate and visible benefits, the know-how to address such problems generates institutional and national knowledge capital for the north. In the current global realities, where the global is local and the local is global, the mutual benefits from such cooperation should not be underestimated and, for sure, not overlooked.

While the modality and scope of partnerships—-to become specific higher education partnerships-are diverse, complex, and numerous, these practices, however, are not always successful; nor are they effective. In many cases, partnerships do not simply live up to expectations for a number of reasons: from paltry financial resources to weak logistical support, from poor planning to substandard execution, from bad policy to cumbersome guidelines, and from unstable leadership to inconsistent follow-up. 


\section{CONCLUSION}

With the declaration of higher education as a vital development tool, multilateral and bilateral regimes, foundations, and other development partners now favor the support of the sector, though still with constrained enthusiasm as the latest African Commission Report (2010) indicates. However, prevalence of competing donor-driven agendas, lack of sustainability, unpredictability of donor resources, poor harmonization, and weak coordination and management still hamper this development.

As the number of institutional partnerships grows, their impact on institutional resources (time, funding, and infrastructure) and institutional dynamics (cohesion, complimentarity, and priorities) may be considerable. This may be particularly so in countries with few "partnerable" institutions, in a region that tends to attract more development support.

Finally, it is imperative that the marketplace of partnerships discoursed in the region is guided by well-informed, responsible, and pragmatic stakeholders in the south and the north. At the end, it is in the best interest of all the stakeholders, both in the north and the south, to have a sustained impact and meaningful outcome in the reengagement with Africa. 